\title{
Food Safety, Fish and Listeriosis
}

\author{
Alejandro De Jesús Cortés-Sánchez ${ }^{1, a,{ }^{* *}, \text { Martha Lorena Guzmán-Robles }^{2, b} \text {, Rodolfo Garza-Torres }}{ }^{1, \mathrm{c}}$, \\ Luis Daniel Espinosa-Chaurand ${ }^{1, d}$, Mayra Diaz-Ramirez ${ }^{3, e}$
}

${ }^{1}$ Consejo Nacional de Ciencia y Tecnología (CONACYT). Unidad Nayarit del Centro de Investigaciones Biológicas del Noroeste (UNCIBNOR+). Calle Dos No. 23. Cd. del Conocimiento. Av. Emilio M. González. Cd. Industrial. C.P. 63173.Tepic, Nayarit. México

${ }^{2}$ Universidad Tecnológica de Nayarit. Carretera Federal $200 \mathrm{Km}$ 9. Xalisco, Nayarit, México

${ }^{3}$ Universidad Autónoma Metropolitana. Unidad Lerma. Departamento de Ciencias de la Alimentación. Lerma de Villada, Estado de México. México

*Corresponding author

\begin{tabular}{|c|c|}
\hline A R T I C LE INFO & A B S T R A C T \\
\hline $\begin{array}{l}\text { Keywords: } \\
\text { Listeria monocytogenes } \\
\text { Food pathogens } \\
\text { Fish processing. } \\
\text { Fishery } \\
\text { Aquaculture }\end{array}$ & $\begin{array}{l}\text { Listeria monocytogenes is a food pathogen responsible for listeriosis, a relevant disease in public } \\
\text { health worldwide. The genus Listeria spp., corresponds to cosmopolitan bacteria and capable of } \\
\text { surviving different adverse conditions, which increases the risk for the food to be contaminated at } \\
\text { any stage of the food chain. Fish and fish products are foods of high production level and, due to } \\
\text { their chemical or nutritional composition, are highly susceptible to deterioration and contamination } \\
\text { by pathogens in their productive chain relating to cases of listeriosis. Derived from the incidence } \\
\text { and human mortality due to causative agents of listeriosis, along with their resistance to } \\
\text { antimicrobials, they have acquired a greater emphasis on human health, animal health and food } \\
\text { industry, resulting in the implementation of safety systems such as good hygiene practices, Hazard } \\
\text { Analysis and Critical Control Points (HACCP) system, analytical methods and microbiological } \\
\text { criteria, as some of the actions to contribute to the food safety and public health protection. The } \\
\text { purpose of this review document is to provide, in a general way, aspects involved in foodborne } \\
\text { illnesses, specifically listeriosis and its association with fish as a transmitting food, considering the } \\
\text { prevention and control measures of this disease through food. It also includes aspects related to } \\
\text { antimicrobial resistance by bacterial isolates obtained from fish, their implications and health risks. }\end{array}$ \\
\hline
\end{tabular}

\author{
(iD) https://orcid.org/0000-0002-1254-8941 \\ (iD https://orcid.org/0000-0002-7179-0711 \\ (iD) https://orcid.org/0000-0002-6087-7053
}

(iD) https://orcid.org/0000-0002-6353-2907 (iD) https://orcid.org/0000-0002-0587-5549

\section{Introduction}

The human being presents the imperative need for food and has the right to consume safe foods that do not contain physical, chemical or biological agents at levels that, or of a nature that, endanger their health in terms of accessing and consumption of safe food (Tafur, 2009; De la Fuente and Barboza, 2010). Food safety has become a vital attribute in all phases of production, constituting along with nutritional, organoleptic and commercial characteristics, total quality (Tafur, 2009; De la Fuente and Barboza, 2010). A food through its different stages of production ranging from obtaining, processing, handling, storage and prior to consumption can be exposed to different pollutants of biological origin, like bacteria such as: Aeromonas hydrofila, Bacillus cereus, Clostridium botulinum, Clostridium perfringens, Escherichia coli, Staphylococcus aureus, Listeria monocytogenes, Plesiomonas shigueloides, Salmonella spp., Shigella spp.,
Vibrio spp., Campylobacter spp., among others, and thus compromise food safety by being a potential disease generator (De La Fuente and Barboza, 2010; Soto et al., 2016; CDC, 2018). In recent years, foodborne illnesses have shown an increase in their incidence and mortality, becoming a major health problem worldwide, and a common concern in consumers, producers, regulators, trade and health organizations (Tafur, 2009; Soto et al., 2016; CDC, 2018). The purpose of this document is to present, in a general way, some aspects involved in foodborne diseases, specifically listeriosis and its association with fish as a transmitting food, considering the prevention and control measures of this disease in food, including also referring aspects to the antimicrobial resistance by isolates obtained from fish its implications and health risks. 


\section{Foodborne Diseases}

Foodborne diseases (FD) are those diseases derived from the ingestion of food and water contaminated with chemical substances or biological agents, affecting the health of the consumer (Soto et al., 2016; WHO, 2019).

The clinical manifestations of these diseases are gastrointestinal symptoms such as nausea, vomiting, diarrhea, abdominal pain, fever, and in some cases severe complications such as sepsis, meningitis, abortions, Reiter's syndrome, Guillan Barré syndrome, or death (Soto et al., 2016; WHO, 2019). These diseases are considered a growing problem in public health at a global level due to their incidence, mortality and negative socio-economic impact (productivity, trade, and expenses associated with hospitalization and treatments), and in addition the fact that the problem with these diseases increases with the appearance of new forms of transmission, vulnerable population groups, and the increase in bacterial resistance (Soto et al., 2016; Palomino et al., 2018; WHO, 2019), it is estimated that approximately 600 million people get sick annually around the world by consuming contaminated food, where 420,000 die from this same cause (WHO, 2017).

Approximately there are more than 250 causative agents of foodborne diseases, where their incidence has increased during the last years due to factors such as the globalization of the food market, and changes in eating habits (Palomino et al., 2018). Among the most common foodborne diseases they are those caused by biological agents, such as bacteria, among which are: Campylobacter jejuni, Clostridium botulinum, Clostridium perfringens, Escherichia coli, Salmonella spp., Shigella spp., Staphylococcus aureus, Vibrio cholerae, Vibrio parahaemolyticus, Yersinia enterocolitica, Listeria monocytogenes, among others (Cortés et al., 2016; Palomino et al., 2018; Hernandez et al., 2017; FDA, 2017; Heredia and García, 2018). It should be pointed that animals destined for food production are considered a reservoir for the different causative agents of food diseases, highlighting that contamination can occur at any stage of food production until its consumption (Heredia and García, 2018; WHO, 2019).

\section{Listeria Generalities}

The bacterial genus of Listeria is divided into 17 species that are: Listeria monocytogenes, Listeria ivanovii, Listeria seeligeri, Listeria welshimeri, Listeria marthii, Listeria innocua, Listeria grayi, Listeria fleischmannii,
Listeria floridensis, Listeria aquatica, Listeria newyorkensis, Listeria cornellensis, Listeria rocourtiae, Listeria weihenstephanensis, Listeria grandensis, Listeria riparia, and Listeria booriae. Only L. monocytogenes and L. ivanovii are described as pathogenic in humans and animals (Hernandez, 2010; Heredia and García, 2018). The phenotypic characteristics of Listeria correspond to being Gram positive bacilli, positive catalase, anaerobes or facultative microaerophils, mobile at $25^{\circ} \mathrm{C}$ and immobile at temperatures of $35^{\circ} \mathrm{C}$ (Domínguez, 2010). Listerias are ubiquitous in nature in plants, soil, water, food and human and animal excrement (Acha and Szyfres, 2001; Domínguez, 2010; Cortés et al., 2016; Heredia and García, 2018; Elika, 2019). In addition, they are microorganisms capable of surviving different adverse conditions withstanding high salt concentrations (for L. monocytogenes $>20 \%$ ), temperatures from $3^{\circ} \mathrm{C}$ to $45^{\circ} \mathrm{C}$, and $\mathrm{pH}$ between 5.6 to 9.6 (Castañeda et al., 2014; Mercado and Moreno, 2015). In Table 1 shows various biochemical tests for the identification of species of the genus Listeria spp.

L. monocytogenes is an intracellular pathogen in humans and animals, and its infection results in listeriosis, an invasive disease transmitted by different routes (fecaloral, animal-man and mother-fetus), being the food route the main source of transmission through contaminated food, presenting a high mortality rate (20-30\%) that affects, mainly, populations of high susceptibility or risk such as: immunosuppressed, pregnant, newborns and older adults (Torres et al., 2005; Hernandez, 2010; Herrera and Suarez, 2012; Castañeda, 2014; Mercado and Moreno, 2015).

The incubation period of the disease can be between one and several weeks, being the dose infectious unknown yet; however, it is estimated that it may be less than 100 viable cells $/ \mathrm{g} / \mathrm{mL}$ (Herrera and Suarez, 2012). Other researchers estimate a dose of $10^{4}-10^{6} \mathrm{CFU} / \mathrm{g}$ of ingested food. Nevertheless, in any of the cases, the dose will depend on the food, virulence of the strain and susceptibility of the host (Castañeda et al., 2014).

Infection by this pathogen involves several phases, which are: adhesion and invasion of the host cell, escape of the vacuole, intracellular multiplication, and extracellular proliferation, where multiple virulence factors are involved in each phase, such as: listeriolysin $\mathrm{O}($ hly), phosphatidylinositol phospholipase $\mathrm{C}$ (plcA), phosphatidylcholine phospholipase $\mathrm{C}(\mathrm{plcB})$, zinc metalloprotease precursor $(\mathrm{mpl})$, positive regulatory factor $\mathrm{A}$ ( $p r f A)$, actin assembly inducing protein (actA), hexose phosphate transporter protein (hpt), Internalin A (inlA), Internalin B (inlB), Internalin C (inlC), and internalin J (inlJ) (Vera et al., 2013).

Table 1 Biochemical tests for the identification of species of the genus Listeria (Cortés et al., 2016; Hitchins et al., 2017).

\begin{tabular}{|c|c|c|c|c|c|c|}
\hline \multirow{3}{*}{ Bacteria } & \multicolumn{6}{|c|}{ Test } \\
\hline & \multicolumn{2}{|c|}{ Sugar fermentation } & \multirow{2}{*}{ Mannitol } & \multirow{2}{*}{$\beta$-hemolysis } & \multirow{2}{*}{ HESA } & \multirow{2}{*}{ HERE } \\
\hline & Xyl & Rha & & & & \\
\hline L. monocytogenes & - & + & - & + & + & - \\
\hline L. ivanovii & + & - & - & + & - & + \\
\hline L. innocua & - & $\mathrm{v}$ & - & - & - & - \\
\hline L. welshimeri & + & $\mathrm{V}$ & - & - & - & - \\
\hline L. seeligeri & + & - & - & + & $+*$ & - \\
\hline L. grayi subsp. grayi & - & - & + & - & - & - \\
\hline L. grayi subs. murrayi & - & $\mathrm{v}$ & + & - & - & - \\
\hline
\end{tabular}

HESA: Hemolysis enhancement with $S$. aureus (S). Test Christie-Atkins-Munch-Peterson (CAMP), HERE: Hemolysis enhancement with Rhodococcus equi (R). Test Christie-Atkins-Munch-Peterson (CAMP), $+^{*}=$ Weak reaction, $\mathrm{V}=$ Variable reaction,$+=>90 \%$ of positive reaction, $-=$ no reaction. $\mathrm{Xyl}=$ Xylose, Rha=Rhamnose. 
Listeriosis can be one of two main types: invasive and non-invasive. Non-invasive or febrile gastroenteritis is the mild form that mainly affects healthy people and usually associated with the intake of foods with high bacterial load; its symptoms include diarrhea, fever, headache and muscle aches. Meanwhile, the invasive form is more serious, affecting high-risk groups; some of its symptoms are fever, muscle aches, pneumonia, gastroenteritis, encephalitis, septicemia, and meningitis (Vera et al., 2013; WHO, 2018; Elika, 2019).

The severity of this disease and its association with the consumption of processed foods make the social and economic impact of listeriosis high compared to other foodborne diseases (Hernandez, 2010). L. monocytogenes, according to differences in somatic $(\mathrm{O})$ and flagellar $(\mathrm{H})$ antigens, has been identified in 13 pathogenic serovars that are: 1 / 2a, 1 / 2b, 1 / 2c, 3a, 3b, 3c, 4a, 4b, 4ab, 4c, 4d, 4e and 7 , classified into 5 genoserogroups IIa (1 / 2a, 3a), IIb (1 / 2b-3b-7), IIc (1 / 2c-3c), IVa (4a- 4c), and IVb (4ab$4 \mathrm{~b}, 4 \mathrm{~d}-4 \mathrm{e}$ ) (Wieczorek and Osek, 2017). The most serotypes, related to food and described in cases of human listeriosis, are 4b, 1/ 2b, 1 / 2a and 1/ 2c (Hernandez, 2010; Cortés et al., 2016; Wieczorek and Osek, 2017).

L. monocytogenes has been located in ready-to-eat foods such as beef, chicken, fish, shellfish, fruits, vegetables, milk and dairy products, turning them into high risk vehicles for infection (Acha and Szyfres, 2001; Buchanan et al., 2017; FDA, 2017; Heredia and García, 2018; Elika, 2019). For food safety, it is noteworthy that it is a psychrotrophic microorganism, capable of growing at refrigeration temperatures and surviving freezing (Hernandez, 2010; Cortés et al., 2016; Elika, 2019) so that the food associated mostly to outbreaks of listeriosis are those with extended storage periods at refrigeration temperatures and consumed without any previous heat treatment (WHO, 2018). In addition, this bacterium can adhere and grow on surfaces forming colonies protected with layers of extracellular polymeric substances (polysaccharides, proteins and DNA) that provide protection against unfavorable agents in their environment, including antimicrobial agents; these structures are called biofilms and allow microbial survival, and are a source of contamination in food production and a health risk (Elika, 2006; Colagiorgi et al., 2016; Elika, 2019).

\section{Fish and Food}

Fish is one of the most commercialized food products worldwide. Through fishing and aquaculture activities, it is an important source of food, nutrition, income and livelihoods for hundreds of millions of people. Until 2014, the global supply of fish per inhabitant had reached a new maximum of $20 \mathrm{~kg}$, due to the growth of aquaculture (FAO, 2016).

Fish is considered a food with excellent nutritional qualities as it has a high level of protein, is easily digestible, and a source of lipids that involve $\boldsymbol{\omega}-3$ polyunsaturated fatty acids (Lopes et al., 2008). Despite these nutritional qualities, fish can undergo a series of biochemical changes from the moment of its capture, making it a product of high susceptibility to spoilage and decay, where the main responsible factors are the enzymes that constitute them and microorganisms that invade organs and tissues once death has occurred (Lopes et al., 2008; Ramirez et al., 2011).
In the growth and cultivation of fish, they have a microbial population dependent on what is present in the waters where they live. The bacteria found in the skin and gastrointestinal content of the fish alive do not invade the muscle pack, it is sterile since the body is protected by its natural defenses. However, when it dies, these bacteria penetrate into the fish (Romero and Negrete, 2011). Bacteria are the most influential microorganisms in the shelf life and safety of fish as food. Its qualitative and quantitative characters in the capture are in relation to the time of the year, feeding, geographical area, species of fish and capture system, while post-capture conditions such as handling, processing and storage determine the altering microbiota and pathogenic, and therefore its microbiological quality, becoming potential vehicles for consumer diseases (Farias et al., 2008; Romero and Negrete, 2011; Ramírez et al., 2011).

Bacteria present in the fish of interest in public health that cause diseases to humans after consumption can be of two origins: 1 . Indigenous: this group is widely distributed in aquatic environments around the world having temperature a selective effect (Clostridium botulinum, Listeria monocytogenes, Vibrio spp., Aeromonas hydrophila, Plesiomonas shigelloides), and 2. No indigenous, such as Salmonella spp., E. coli, Shigella spp., $S$. aureus, derived from fish contamination due to poor handling or growth practices in polluted waters (Huss, 1993; Fuentes et al., 2011).

Fresh fish, as food and its relationship with processing conditions and conservation, has different characteristics such as: its high nutrient content, $\mathrm{pH}$ from 6.6 to 6.8 ; water activity $\left(\mathrm{a}_{\mathrm{w}}\right)$ from 0.98 to 0.99 ; oxide-reduction potential, between +100 to $+>300 \mathrm{mv}$ and prolonged storage times at cooling temperatures that favor the growth of different microorganisms, including Listeria monocytogenes, which compromise their safety (Lopes et al., 2008; Herrera and Suarez et al., 2012; Soares and Gonçalves, 2012). In addition, since Listeria species are cosmopolitan in nature, they have been isolated from rivers, sea and sewage, so the possible cross-contamination with the environment during fish production and processing is a factor in the hygiene of this food (Herrera and Suarez et al., 2012). Foods derived from fish that have been related the most to listeriosis outbreaks in humans are raw products, or those processed products that do not need heat treatment or cooking prior to consumption, such as smoked fish (Zorn and Suarez, 2009; Muñoz et al., 2011).

On a regular basis, food contamination by Listerias, including fish all along the food chain, derives from different events, such as: a) food and sources of environmental pollution; b) conditions that favor the growth of the pathogen, and c) absence or inadequate hygiene practices and surveillance programs in the food chain (Castañeda et al., 2014).

The increase in fish production and consumption around the world (Lopes et al., 2008; FAO, 2016), in addition to changes in healthier eating habits and practices, weight control, cultural globalization, consumption of packaged foods, meals outside house, sale of prepared foods and fast foods, among others, have in some cases favored the consumption of raw fish and by-products, and these have contributed to raising the risk of incidence of foodborne diseases (Lopes et al., 2008; Olea et al.,2012). 


\section{Control and Prevention of Listeriosis}

The European Food Safety Authority (EFSA) and the European Center for Disease Prevention and Control (ECDC), in its report on trends and sources of zoonoses, zoonotic agents and outbreaks of foodborne diseases of 2017, stated 2,480 cases of listeriosis, showing the population group of the elderly (> 84 years) with a mortality rate of $24 \%$. In general, in the European Union, the infection was fatal for one in 10 patients, where the highest levels of L. monocytogenes were detected in fish and fishery products $(6 \%)$, followed by ready-to-eat salads (4.2\%) (EFSA and ECDC, 2018).

In the United States of America, through the Centers for Disease Control and Prevention (CDC) by the detection and typing of L. monocytogenes, it reports approximately 1500 cases of listeriosis associated with food consumption annually with a mortality rate of $17 \%$ (Castañeda et al., 2019).

In Mexico, the presence of L. monocytogenes has been reported in several foods; however, the clinical cases described are few, the aforementioned possibly derived from the fact that listeriosis is not a disease whose declaration is mandatory. On the other hand, in general, developing countries do not consider the listeriosis report mandatory, a reason that could possibly imply the low incidence of the disease (Castañeda et al., 2019).

L. monocytogenes is relevant in food production due to its impact on health (Hernandez, 2010). In the food industry, products like dairy, meat, fish and vegetables, this pathogen puts them in need for the implementation of barriers, by part of food processing industries, to minimize their entry to the processing sites, and specifically in the stages where the food does not receive a treatment that allows the destruction of the pathogenic microorganism; for example in fish, in the hot smoking process $\left(>\right.$ at $\left.68^{\circ} \mathrm{C}\right)$ it has a pasteurization effect; however, cold smoking (18$28^{\circ} \mathrm{C}$ for $18 \mathrm{~h}$ ) can allow the development of $L$. monocytogenes, being considered this among the readyfor-consumption goods of high health risk (Mercado and Moreno, 2015). The importance in food safety of $L$. monocytogenes is remarkable in the industry because it can even become endemic to food processing infrastructure through the development capacity of biofilms, which makes it difficult to eliminate or inactivate, generating a high risk to health (Hernandez, 2010).

The ubiquity in nature and tolerance to survive under different adverse conditions for prolonged periods of time by the Listerias, the severity and lethality of listeriosis in public health, have led the agri-food industry to manifest a greater demand in the control of food hygiene that may be contaminated at any stage of the food chain, including production, processing, and cold storage; it also emphasizes the implementation of food safety guidelines and plans through the application of good aquaculture practices, good fishing practices, good manufacturing practices (GMP), sanitation operating procedures (SSOP), and Hazard Analysis and Critical Control Points (HACCP), in production processes including validation through microbiological tests (Domínguez, 2010; Mercado and Moreno, 2015; Rodrigues et al., 2017; Palomino et al., 2018; WHO, 2018). On the other hand, international organizations, such as the Food and Agriculture
Organization (FAO), through the Codex Alimentarius, have issued the guidance (CAC /GL61-2007) for the application of general principles of food hygiene for the control of L. monocytogenes in order to generate safe food all along the food chain (FAO, 2019a).

Around the world, in matters of food legislation, control and prevention of listeriosis outbreaks derived from the consumption of contaminated food have been established. In the European Union, among the food processing companies, it is the implementation of general hygiene measures based on Regulation (EC) "852/2004", and microbiological criteria according to Regulation (EC) “2073/2005" and Regulation (EC) "1441/2007”, which act as guidance on the acceptability of food products and manufacturing, handling and distribution processes, and that are part of the application of Hazard Analysis Procedures and Critical Control Points (HACCP), and other hygiene control measures. For L. monocytogenes the permissible microbiological criteria in high-risk foods such as those ready for consumption, intended for infants and special medical uses is the absence in $25 \mathrm{~g}$ of product marketed during its shelf life, while ready-to-eat foods that can to favor the development of Listeria monocytogenes, not intended for infants or special medical uses, the microbiological criteria is the absence of the pathogen in $25 \mathrm{~g}$ of product and the analytical reference methods (ISO) "11290-1 and 11290-2" (EC 852/2004; EC 2073/2005; Elika, 2019). In Latin America, in order to control and reduce listeriosis, countries such as Mexico present, in their sanitary regulation of foods like fishery products and in the official Mexican standard "NOM-242-SSA1-2009", the microbiological specification for Listeria monocytogenes which specifies that it must be absent in $25 \mathrm{~g}$ of food sample. In South America, countries like such, through the ministerial resolution "RM N ${ }^{\circ} 615-2003$ ", have established the microbiological criteria of sanitary quality and safety for food and beverages for human consumption, indicating that, for foods such as ice cream and aged / no aged cheeses, L. monocytogenes must be absent in $25 \mathrm{~g}$ of sample. Meanwhile, in Brazil, the Ministry of Agriculture Livestock and Food Supply (MAPA) has established that microbiological control in ready-for-consumption, animal origin products with a $\mathrm{pH}$ above 4.4 , water activity greater than 0.92 , and $\mathrm{NaCl}$ concentration less than $10 \%$ with conditions favorable to microbial growth, the criteria adopted for L. monocytogenes is that there must be an absence of it in 25g of food (Rodrigues et al., 2017).

On the other hand, within the control and prevention measures aimed at the general population, recommendations have been issued by health entities that indicate that L. monocytogenes, when present in food, can be eliminated by the action of heat treatments prior to consumption such as pasteurization and cooking. Likewise, among other preventive measures, food handling has been stipulated in hygienic conditions consisting of: 1 . Maintain cleanliness; 2 . Separate raw and cooked food; 3. Cook completely; 4. Keep food at safe temperatures; 5 . Use water and safe raw materials; in addition, people in highrisk groups are recommended to avoid eating ready-to-eat foods that include meat products, unpasteurized dairy products, fruits, raw sprouts (alfalfa, clover or radish), fish, and smoked seafood (WHO, 2018; Elika, 2019; CDC, 2019). 
Isolation and Detection of Listeria spp., in the Laboratory

Microbiological food analysis methods are part of the food pathogen control and prevention system, in order to guarantee food safety and protect public health. Around the world, different traditional microbiological methods for the isolation and detection of Listeria species have been developed and proposed, which commonly involve the use culture media of enrichment, selective and differential culture media, and subsequent confirmation through biochemical tests (Table 1), and serological. Some of these methods are standardized and used in regular food surveillance around the world. Among the aforementioned methods they are the present in the Bacteriology Analytical Manual (BAM) of the U.S. Food and Drug Administration (US FDA)(Hitchins et al., 2017), the method reported by the United States Department of Agriculture, Food Safety and Inspection Service, at the Microbiology Laboratory Guidebook- MLG 8.11- (USDA, 2019); in Europe it is found the Standard Method-FNES22, version 4- of Public Health England (PHE)(Figure 1 and 2), and methods for detection and enumeration of Listeria monocytogenes and of Listeria spp., by the International Standardization Organization (ISO) "11290-1" and "11290-2" (Cortés et al., 2016; Wieczorek, and Osek, 2017; PHE, 2018). Regarding the regulation and sanitary quality for fishery products, in Latin American countries such as Mexico, it exists the official standard "NOM-210-SSA1-2014" that establishes the method for isolation and detection of Listeria spp., in food such as fishery products (Cortés et al., 2016). On the other hand, alternative molecular methods have been developed, fast and sensitive for the detection and identification of Listeria spp., through the polymerase chain reaction (PCR), in order to avoid the inconvenience of longer times for obtaining results by traditional methods; those are also used for typing and molecular differentiation, while epidemiological studies being developed and commonly used are the Pulsed-Field Gel Electrophoresis (PFGE), Multilocus Sequence Typing (MLST), Multilocus Variable-Number Tandem Repeat Analysis (MLVA), and Whole Genome Sequencing (WGS) (Chen et al., 2011; Cardozo et al., 2013; Kwong et al., 2015; Abdollahzadeh et al., 2016; Hitchins et al., 2017; PHE, 2018).

\section{Antimicrobial Resistance}

Antimicrobial resistance is the biological phenomenon where a microorganism (mainly bacteria) is able to resist, and not being affected by the growth inhibitory activity or destruction of an antimicrobial to which it was previously sensitive (Verraes et al., 2013; WHO, 2019). Antimicrobial resistance constitutes a major global threat to human and animal health, due to increased morbidity, mortality and high health costs in treatment; it is also considered a threat to food production and food safety (García, 2012; FAO, 2019) as a relationship has been established between the use of antimicrobials in different phases of the food chain and transfer routes that might bring potential health risks (Verraes et al., 2013). It is estimated that every year around the world 700,000 people die from infections caused by pathogenic microorganisms resistant to antimicrobials (FAO, 2017).

It has been established that antimicrobial resistance has been generated by the inappropriate and indiscriminate use of antimicrobials in humans and animals; in the latter, agricultural, livestock and aquaculture activities have contributed significantly to this phenomenon of resistance through the use of antimicrobials with therapeutic, prophylactic and growth promotion functions (Puig et al., 2011; Rocha et al., 2015).

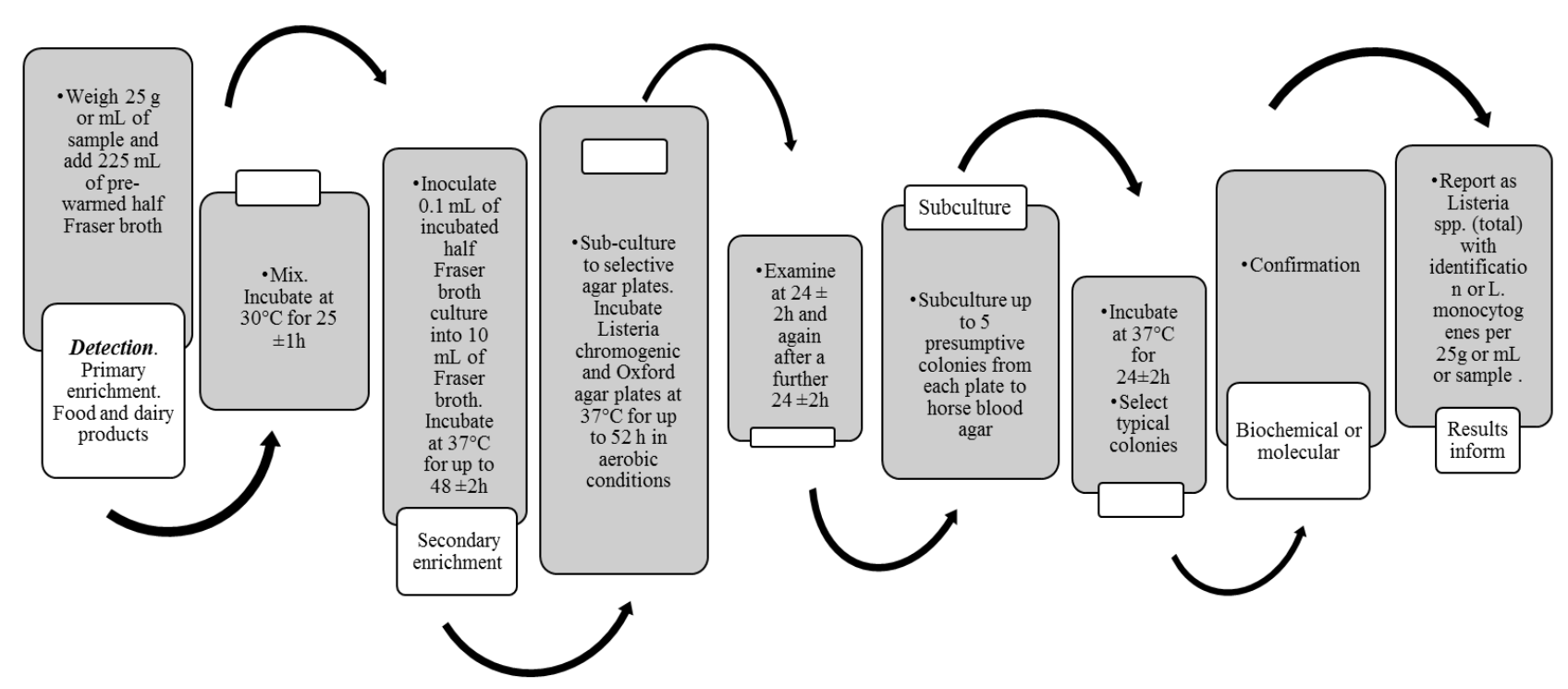

Figure 1 Flowchart for the detection of Listeria monocytogenes and other Listeria spp., in food (PHE, 2018) 


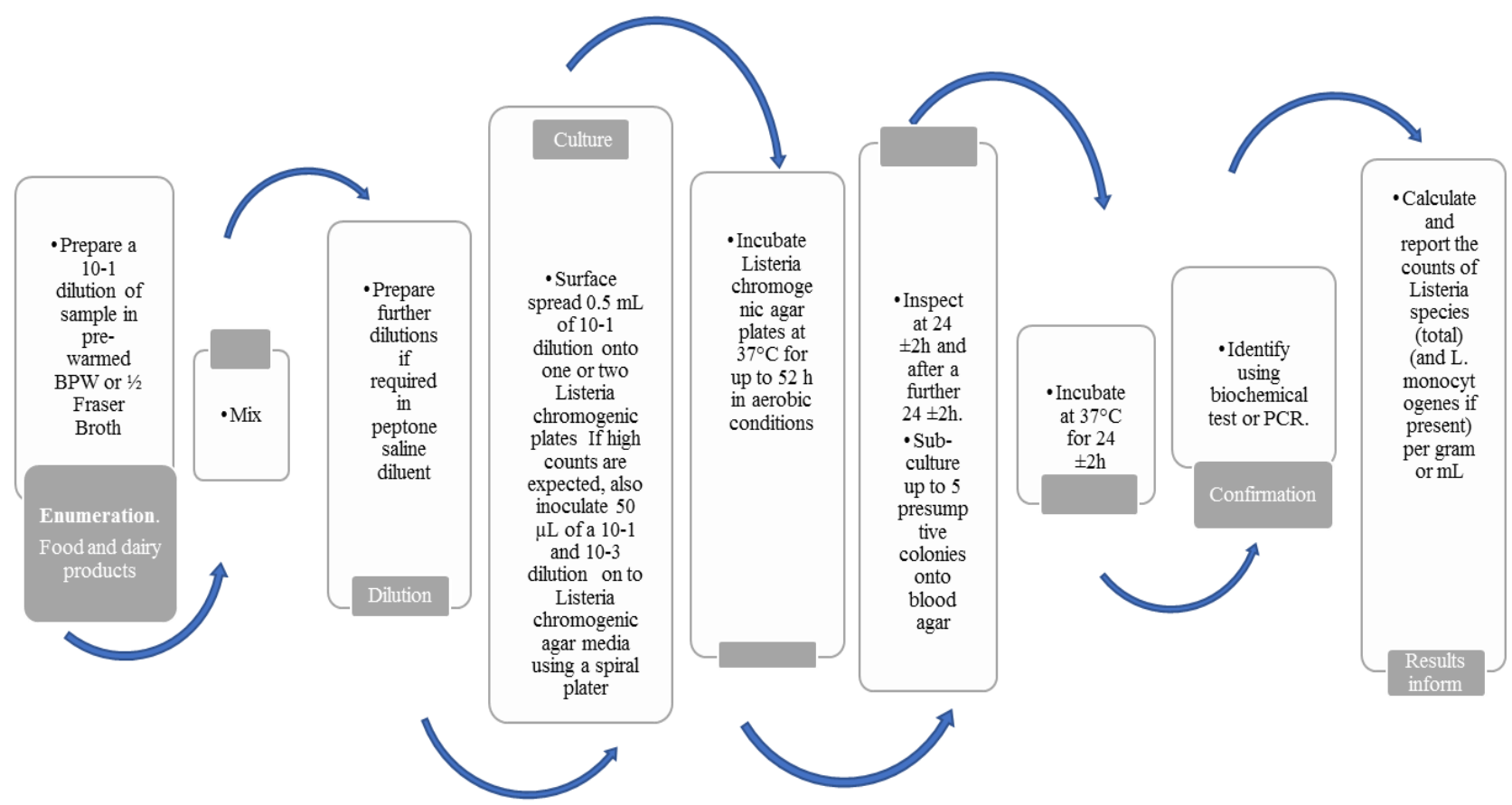

Figure 2 Flowchart for the enumeration of Listeria monocytogenes and other Listeria spp., in food (PHE, 2018)

Antimicrobial resistance in bacteria is split into two different types: 1. Natural or intrinsic, which is stable and vertically transmitted (daughter cells), and 2. Acquired through mutations in chromosomes (spontaneous, stable and vertical transmission) or by exchange of resistance genes through horizontal transfer by processes of: conjugation (plasmids, integrons and transposons), translation, and transformation that takes place in diverse environments such as water, soil, animal digestive system or food (Gonzalez et al., 2004; Verraes et al., 2013; Quiñones, 2017).

The mechanisms to resist the action of antimicrobials by bacteria are varied. Among those are: the modification of membrane permeability, excretion pumps, enzymatic modification, attack target modification or alteration of the composition, and content of cell wall glycoproteins (Tafur et al., 2011; Puig et al., 2011).

The constant monitoring of the course and nature of the acquisition and dissemination of antimicrobial resistance by microorganisms is a global concern, and especially for pathogenic species of the genus Listeria spp., has become almost an obligation for all isolations coming from environments, clinical infections, and mainly those from food, which play a significant role in the development and spread of antimicrobial resistance and public health risk (Mercado and Moreno, 2015; FAO, 2019).

Currently, the combination of ampicillin or amoxicillin, and rifampicin with gentamycin are the primary choices in the treatment of human listeriosis, while vancomycin, trimethoprim-sulfamethoxazole and erythromycin are considered second-choice antibiotics for pregnant women (Conter et al., 2009; Abdollahzadeh et al., 2016).

On the other hand, some studies around the world focused on the isolation of strains of Listeria spp., from food, specifically fish products, have reported resistance to different antimicrobials including those used in the treatment of listeriosis, indicating a high risk to the health of consumers.
Conter et al. (2009) reported the isolation of 120 strains of L. monocytogenes from different foods such as smoked fish, raw, and salads; subsequently, they evaluated the antimicrobial susceptibility of these strains, indicating that $55.8 \%$ showed resistance to oxacillin, $(0.8 \%)$ to Cyprofloxacin, $(0.8 \%)$ to moxifloxacin, $(0.8 \%)$ to clindamycin, $(1.7 \%)$ to linezolid, $(0.8 \%)$ to vancomycin, $(0.8 \%)$ to tetracycline, (49.2) to fosfomycin, (47.5) to fusidic acid, and (1.7\%) to Trimethoprim / sulfamethoxazole.

Abdollahzadeh et al. (2016) analyzed the susceptibility to antimicrobials (ampicillin, penicillin, gentamycin, streptomycin, tetracycline, trimethoprimsulfamethoxazole, chloramphenicol, and cefotaxime) of 7 isolates of L. monocytogenes from fish and shellfish and 7 of clinical samples, showing that the isolates have a high level of resistance to ampicillin, cefotaxime (100\%), and pencillin $(57 \%$ in seafood isolates and $71.4 \%$ in clinical isolates).

Wieczorek, and Osek, (2017) performed the isolation of L. monocytogenes from several species of fresh and smoked fish in Poland, where from a total of 301 samples 57 were positive for this bacterium; also, performing the resistance analysis to 17 antimicrobial of the isolates, reporting that several of them presented resistance to oxacillin, ceftriaxone or clindamycin.

The researchers conclude that L. monocytogenes is becoming resistant to antibiotics, which constitutes a potential risk to the health of consumers through fishery products, which allows the implementation of regular monitoring of the antimicrobial resistance of this pathogen in food and environment, which will be transcendental in future epidemiological studies, food contamination, effective treatments for human listeriosis, and protection of public health (Conter et al., 2009; Abdollahzadeh et al., 2016; Wieczorek, and Osek, 2017).

The actions taken against antimicrobial resistance in food production involve the implementation of good 
hygiene practices throughout the food chain. While international organizations, such as the Food and Agriculture Organization of the United Nations (FAO) through the Codex Alimentarius, have developed codes of practice focused on the use and management of veterinary drugs and their residues, food hygiene and animal nutrition to minimize and contain antimicrobial resistance (CAC/RCP 61-2005), and guidelines for risk analysis of food-transmitted antimicrobial resistance (CAC/GL 772011) which constitute the fundamental axis for food safety and containment of the spread of resistant microorganisms (Puig et al., 2011; Verraes et al., 2013; FAO, 2019).

\section{Conclusions}

L. monocytogenes is considered a causative agent of diseases derived from food consumption (frequently meat products, dairy products, fish and derivatives), its importance in public health is due to its incidence, mortality, costs in health services and in recent years to the emergence of antimicrobial resistant food pathogens.

Fish is considered a very nutritious food, consumed worldwide in different culinary presentations. Due to its chemical and nutritional composition, fish is also a food that is highly susceptible to spoilage and contamination by microorganisms. The cosmopolitan nature of Listeria and its ability to survive adverse conditions, causes the risk of its presence in fish that can be contaminated at any stage of the food chain, making it a high risk food for human health.

Antimicrobial resistance is considered an important challenge for human health and food safety. Various investigations around the world have reported isolates of resistant Listeria monocytogenes present in fish whose causes of dissemination and presence derive from inappropriate use of antimicrobials in the production of these foods. Increasing reports of resistant food pathogen isolates increase the risk and may compromise the therapeutic treatment applied to infections, so that recommendations on the use and control of antimicrobials in human medicine, animal and food production considered key in increasing this resistance phenomenon.

The implementation of good hygiene practices, hazard analysis systems and critical point control (HACCP), regulation and monitoring of the microbiological quality of food along the food chain including food handling, preparation and preservation by the final consumer (from the farm to the table), they constitute different actions that contribute to the control and reduction of foodborne diseases as listeriosis and resistance to antimicrobials by pathogens.

\section{Conflict of Interest}

The authors declare no conflict of interest in the development and publication of this manuscript.

\section{References}

Abdollahzadeh E, Ojagh S M, Hosseini H, Ghaemi EA, Irajian G, Heidarlo MN. 2016. Antimicrobial resistance of Listeria monocytogenes isolated from seafood and humans in Iran. Microb. Pathog. 100: 70-74. DOI: 10.1016/j.micpath. 2016.09.012.
EFSA and ECDC 2018. European Food Safety Authority and European Centre for Disease Prevention and Control, The European Union summary report on trends and sources of zoonoses, zoonotic agents and food-borne outbreaks in 2017. EFSA Journal,16(12): 5500, 262. https://doi.org/10.2903 /j.efsa.2018.5500

Acha, PN, Szyfres B. 2001. Zoonoses and Communicable Diseases Common to Man and Animals. Organización Panamericana de la Salud. Oficina Sanitaria Panamericana, Oficina Regional de la Organización Mundial de la Salud 525 Twenty-third Street, NW Washington, DC 20037, EUA. https://www.paho.org/hq/dmdocuments/2017/AchaZoonosis-Spa.pdf (Accessed 20-05-2019)

Buchanan RL, Gorris LG, Hayman MM, Jackson TC, Whiting RC. 2017. A review of Listeria monocytogenes: an update on outbreaks, virulence, dose-response, ecology, and risk assessments. Food Control, 75: 1-13. https://doi.org /10.1016/j.foodcont.2016.12.016

CAC/GL 61. 2007. Guidelines on the application of general principles of food hygiene to the control of Listeria monocytogenes in foods. Food and Agriculture Organization of the United Nations. World Health Organization. Codex Alimentarius. International Food Standards. http://www.fao.org/fao-who-codexalimentarius/shproxy/en/?lnk=1 andurl=https $\% 253 \mathrm{~A} \% 252 \mathrm{~F} \% 252 \mathrm{Fworkspac}$ e.fao.org\% $252 \mathrm{Fsites} \% 252 \mathrm{Fcodex} \% 252 \mathrm{FStandards} \% 252 \mathrm{FC}$ XG\%2B61-2007\%252FCXG_061e.pdf (Accessed 10-062019)

CAC/RCP 61 .2005. Code of practice to minimize and contain antimicrobial resistance. Food and Agriculture Organization of the United Nations. World Health Organization. Codex Alimentarius. International Food Standards. http://www.fao.org/fao-who-codexalimentarius/shproxy/es/?lnk=1 andurl=https $\% 253 \mathrm{~A} \% 252 \mathrm{~F} \% 252 \mathrm{Fworkspac}$ e.fao.org $\% 252 \mathrm{Fsites} \% 252 \mathrm{Fcodex} \% 252 \mathrm{FStandards} \% 252 \mathrm{FC}$ XC\%2B61-2005\%252FCXP_061e.pdf (Accessed 10-062019)

CAC/GL 77 .2011. Guidelines for risk analysis of foodborne antimicrobial resistance. Food and Agriculture Organization of the United Nations. World Health Organization. Codex Alimentarius. International Food Standards. http://www.fao.org/fao-who-codexalimentarius/shproxy/es/?lnk=1 andurl=https $\% 253 \mathrm{~A} \% 252 \mathrm{~F} \% 252 \mathrm{Fworkspac}$ e.fao.org\%252Fsites $\% 252$ Fcodex $\% 252 \mathrm{FStandards} \% 252 \mathrm{FC}$ XG\%2B77-2011\%252FCXG_077e.pdf (Accessed 05-072019)

Cardozo Bernal ÁM, Ramón Luisa F, Poutou Piñales, Raúl A, Carrascal Camacho AK, Corina Zambrano D. 2013. Pulsedfield gel electrophoresis (PFGE) for the molecular differentiation of Listeria Monocytogenes. Univ. Sci. 18(2): 203-222. DOI: 10.11144/Javeriana.SC18-2.egcp.

Castañeda Ruelas GM, Salazar Jiménez EP, Hernández Chiñas U, Eslava Campos C, Chaidez Quiroz C. 2019. Adhesion capacity and invasion index of $L$. monocytogenes strains isolated from food and clinical cases in Mexico. Revista Bio Ciencias, 6, e456. DOI: http://dx.doi.org/10.15741 /revbio.06.02.03

Castañeda Ruelas G, Eslava Campos C, Castro del Campo N, León Félix J, Chaidez Quiroz C. 2014. Listeriosis in Mexico: Clinical and epidemiological importance. Salud Pública Méx. 56(6): 654-659. http://www.scielo.org.mx/scielo.php?script= sci_arttextandpid=SO03636342014000600016 andlng=esandtlng=es.

CDC. 2018. Foodborne Illnesses and Germs. Centers for Disease Control and Prevention, National Center for Emerging and Zoonotic Infectious Diseases (NCEZID), Division of Foodborne, Waterborne, and Environmental Diseases (DFWED). U.S. Department of Health and Human Services.USA.gov. https://www.cdc.gov/foodsafety/foodborne -germs.html (Accessed 02-05-2019) 
CDC 2019. Listeria (Listeriosis). Centers for Disease Control and Prevention, National Center for Emerging and Zoonotic Infectious Diseases (NCEZID), Division of Foodborne, Waterborne, and Environmental Diseases (DFWED). U.S Department of Health and Human Services.USA.gov. https://www.cdc.gov/listeria/prevention.html (Accessed 1006-2019)

Chen S, Li J, Saleh Lakha S, Allen V, Odumeru J. 2011. Multiplelocus variable number of tandem repeat analysis (MLVA) of Listeria monocytogenes directly in food samples. Int J Food Microbiol. 148(1): 8-14. DOI: 10.1016/j.ijfoodmicro. 2011.04.014.

Colagiorgi A, Di Ciccio P, Zanardi E, Ghidini S, Ianieri A. 2016. A look inside the Listeria monocytogenes biofilms extracellular matrix. Microorganisms, 4(3): 22. DOI: 10.3390/microorganisms4030022

Conter M, Paludi D, Zanardi E, Ghidini S, Vergara A, Ianieri A. 2009. Characterization of antimicrobial resistance of foodborne Listeria monocytogenes. Int J Food Microbiol. 128(3): 497-500. DOI: 10.1016/j.ijfoodmicro.2008.10.018.

Cortés Sánchez AJ, Díaz Ramírez M, Villanueva Carvajal A, Sánchez Mundo ML, García Barrientos R. 2016. Health Risk Derived From Foods, About Listeria monocytogenes. Int. J. Pure App. Biosci. 4(5): 29-41. DOI: http://dx.doi.org/ 10.18782/2320-7051.2398

De La Fuente Salcido NM, Barboza JEC. 2010. Inocuidad y bioconservación de alimentos. Acta Univ. 20(1): 43-52. https://www.redalyc.org/pdf/416/41613084005.pdf

Domínguez Carmona M. 2010. Listeriosis. Una zoonosis emergente de transmisión alimentaria. Monografías de la Real Academia Nacional de Farmacia, 181-218. http://www.analesranf.com/index.php/mono/article/viewFile /1112/1129(Accessed 15-06-2019)

EC. No 2073 2005. 15 November 2005 on microbiological criteria for foodstuffs. Commission Regulation. Official Journal of the European Union. https://eurlex.europa.eu/legal-content/EN/ALL/?uri= CELEX\%3A32005R2073 (Accessed 20-07-2019)

EC. No 852 .2004. 29 April 2004 on the hygiene of foodstuffs. Regulation of the European Parliament and of the Council. https://eur-lex.europa.eu/legal-content/EN/TXT/?uri= CELEX:02004R0852-20090420 (Accessed 20-07-2019)

Elika. 2006. Listeria monocytogenes. Fundación Vasca para la Seguridad Agroalimentaria. http://www.elika.net/datos /riesgos/Archivo21/Listeria.pdf (Accessed 20-07-2019)

Elika. 2019. Listeria. Fundación Vasca para la Seguridad Agroalimentaria. https://seguridadalimentaria.elika.eus/ listeria/ (Accessed 20-05-2019)

FAO. 2017. Resistencia a los antimicrobianos: lo que necesitas saber Resistencia a los antimicrobianos. The Food and Agriculture Organization of the United Nations. (FAO).http://www.fao.org/zhc/detail-events/es/c/452719/ (Accessed 20-07-2019)

FAO. 2019. Antimicrobial Resistance. Food and Agriculture Organization of the United Nations. http://www.fao.org/faowho-codexalimentarius/thematic-areas/antimicrobial-resistance /en/ (Accessed 20-07-2019)

FAO. 2019a. Guidelines. Food and Agriculture Organization of the United Nations. World Health Organization. Codex alimentarius. International Standards. http://www.fao.org /fao-who-codexalimentarius/codex-texts/guidelines/en/ (Accessed 20-07-2019)

FAO. 2016. El estado mundial de la pesca y la acuicultura 2016. Contribución a la seguridad alimentaria y la nutrición para todos. Food and Agriculture Organization of the United Nations. Roma. 224 pp. http://www.fao.org/3/a-i5555s.pdf (Accessed 20-03-2018)

Farias Maria do Carmo A, Freitas José de A. 2008. Qualidade microbiológica de pescado beneficiado em indústrias paraenses. Revista Inst. Adolfo Lutz (Impresso), 67(2): 113-117 http://periodicos.ses.sp.bvs.br/pdf/rial/v67n2 /a05v67n2.pdf
FDA. 2017. Seguridad alimentaria para futuras mamás: Profesionales de la medicina - Los 14 patógenos principales transmitidos por los alimentos. U.S. Food and Drug Administration

https://www.fda.gov/Food/ResourcesForYou/HealthEducato rs/ucm091976.htm (Accessed 20-05-2019)

Fuentes M, Valladares J, Grass G, Pico Y. 2011. Microbial of the public health interest of Oreochromis spp. (Red tilapia) cultured in freshwater floating cages. Revista Cubana de Investigaciones Pesqueras, 28(2): 74-80. https://www.oceandocs.org/bitstream/handle/1834/4662/Ma yel $\%$ c $3 \%$ adn.pdf? sequence $=1$ andis Allowed $=y$

García AC. 2012. Antimicrobial resistance in Peru and Latin America. Acta Méd. Peruana, 29(2): 99-103. http://www.scielo.org.pe/scielo.php?script=sci_arttextandpid $=$ S1728-59172012000200010andlng=esandtlng=es.

Heredia N, García S. 2018. Animals as sources of food-borne pathogens: A review. Animal Nutrition, 4(3):250-255. https:// doi.org/10.1016/j.aninu.2018.04.006

González R, Gerardo, Mella M, Sergio, Zemelman Z, Raúl, Bello T, Helia, Domínguez YM. 2004. Integrons and resistance gene cassettes: structure and role against antimicrobials. Rev. Med. Chile, 132(5): 619-626. http://dx.doi.org/10.4067 /S0034-98872004000500013.

Hernández Cruza PE. 2010. Bacterias patógenas emergentes transmisibles por los alimentos. Monografías de la Real Academia Nacional de Farmacia. 147-179. http://www.analesranf.com/index.php/mono/article/viewFile $/ 1111 / 1128$

Hernández Porras EE, Rosero Torres LE, Parra Barrera EL, Guerrero Montilla JA, Gómez Rubio AL, Moreno J. 2017. Foodborne disease outbreaks studied by molecular techniques. Rev. Salud Publica (Bogota), 19(5), 671-678. https://doi.org/10.15446/rsap.V19n5.52317

Herrera AF, Suárez QW. 2012. Isolation and identification of Listeria spp. from fresh fish samples, marketed in Pamplona (Norte de Santander). Revista U.D.C.A Actualidad and Divulgación Científica, 15(2): 257-265. http://www.scielo.org.co/scielo.php?script=sci_arttextandpid $=$ S0123-42262012000200002andlng=enandtlng=es.

Hitchins AD, Jinneman K, Chen Y. 2017. Detection of Listeria monocytogenes in Foods and Environmental Samples, and Enumeration of Listeria monocytogenes in Foods. Chapter 10 Bacteriological Analytical Manual. U.S. Food and Drug administration. U.S. Department of Health and Human Services.

https://www.fda.gov/Food/FoodScienceResearch/Laboratory Methods/ucm071400.htm (Accessed 20-07-2019)

Huss HH. 1993. Assurance of seafood quality. FAO Fisheries Technical Paper. No. 334. Rome, Food and Agriculture Organization of the United Nations (FAO). 169p. http://www.fao.org/3/T1768E/T1768E00.htm

ISO. 1996. 11290. Microbiology of food and animal feeding stuffs -Horizontal method for the detection and enumeration of Listeria monocytogenes - Part 1: Detection method. International Organization for Standardization, firts edition (1996).

ISO. 1998. 11290. Microbiology of food and animal feeding stuffs - Horizontal method for the detection and enumeration of Listeria monocytogenes - Part 2: Enumeration method. International Organization for Standardization, firts edition (1998).

Lopes da Silva M, Matté Glavur R, Matté MH. 2008. Sanitary aspects of fish commercialization in street markets of the city of São Paulo, SP/Brazil. Rev. Inst. Adolfo Lutz (Impresso), 67(3): 208214. http://periodicos.ses.sp.bvs.br/pdf/rial/v67n3/a08v67n3.pdf Mercado MP, Moreno CYL. 2015. Antibacterial sensibility of Listeria cultures isolated places of fish expenditure of markets from Trujillo City (Peru). Revista Rebiol, 35(1): 70-76. http://revistas.unitru.edu.pe/index.php/facccbiol/article/viewFile /878/807 
Muñoz AI, Vargas M, Otero L, Díaz G, Guzmán V. 2011. Presence of Listeria monocytogenes in ready-to-eat foods available in open markets, delicatessens and supermarkets, Bogotá, 2002-2008. Biomédica, 31:428-39. http://www.scielo.org.co/scielo.php?script=sci_arttextandpid $=$ S0120-41572011000300015andlng=enandtlng $=$ es.

NOM. 2015. NOM-210-SSA1-2014. Norma Oficial Mexicana, Productos y servicios. Métodos de prueba microbiológicos. Determinación de microorganismos indicadores. Determinación de microorganismos patógenos. http://dof.gob.mx/nota_detalle.php?codigo=5398468andfech $\mathrm{a}=26 / 06 / 2015$ (Accessed 18-06-2019)

NOM. 2009. NOM-242-SSA1-2009. Norma Oficial Mexicana, Productos y servicios. Productos de la pesca frescos, refrigerados, congelados y procesados. Especificaciones sanitarias y métodos de prueba. http://www.dof.gob.mx /normasOficiales/4295/salud2a/salud2a.htm (Accessed 1806-2019)

Olea A, Díaz J, Fuentes R, Vaquero A, García M. 2012. Foodborne disease outbreaks surveillance in Chile. Rev. Chilena Infectol. 29(5): 504-510. DOI: 10.4067/S071610182012000600004

Palomino Camargo C, González Muñoz Y, Pérez Sira E, Aguilar VH. 2018. Delphi methodology in food safety management and foodborne disease prevention. Rev Peru Med Exp Salud Publica. 35(3): 483-490. https://doi.org/10.17843/rpmesp. 2018.353.3086

PHE. 2018. Public Health England, Detection and Enumeration of Listeria monocytogenes and other Listeria species. National Infection Service, Food, Water and Environmental Microbiology Standard Method FNES22 (F19); Version 4. https://www.gov.uk/government/publications/detection-andenumeration-of-listeria-monocytogenes-and-other-listeriaspecies (Accessed 18-07-2019)

Puig PY, Espino HM, Leyva CV. 2011. Resistencia antimicrobiana en Salmonella y E. coli aisladas de alimentos: revisión de la literatura. Panorama. Cuba y Salud, 6(1): 30 38. http://www.redalyc.org/pdf/4773/477348944006.pdf

Quiñones Pérez D. 2017. Antimicrobial resistance: evolution and current perspectives in the context of the "One health" approach. Rev. Cubana Med Trop. 69(3): 1-17. https://www.medigraphic.com/pdfs/revcubmedtro/cmt2017/cmt173i.pdf

Ramírez LCC, Ospina MAÁ, Fonseca LAC, Beltran YCC. 2011. Bacteriological quality of fresh fish, Catfish (Pseudoplatystoma sp.) and Red Tilapia (Oreochromis sp.), as marketed in the municipality of El Colegio, Cundinamarca (Colombia). NOVA - Publicación Científica en Ciencias Biomédicas, 9(15): $113-214$.

RMN. 2003. RM N $\mathrm{N}^{\circ}$ 615-2003. Criterios microbiológicos de calidad sanitaria e inocuidad para los alimentos y bebidas de consumo humano. Resolución ministerial. Republica del Perú.https://www.saludarequipa.gob.pe/desa/archivos/Norm as_Legales/alimentos/RM591MINSANORMA.pdf (Accessed 18-03-2019)

Rocha C, Reynolds ND, Simons MP. 2015. Emerging antibiotic resistance: a global threat and critical healthcare problem. Rev Peru Med Exp Salud Publica, 32(1): 139-145.

Rodrigues CS, SáCVGCD, Melo CBD. 2017. An overview of Listeria monocytogenes contamination in ready to eat meat, dairy and fishery foods. Ciência Rural, 47(2). http://dx.doi.org/10.1590/0103-8478cr20160721
Romero JJM, Negrete RMP. 2011. Presence of Gram negative bacteria in fish muscle of commercial importance in the Mexican Caribbean zone. Rev Mex Biodivers. 82(2): 599-606. http://www.scielo.org.mx/scielo.php?script=sci_arttextandpi $\mathrm{d}=$ S1870-34532011000200019andlng=esandtlng=es.

Soares Karoline MP, Gonçalves AA. 2012. Seafood quality and safety. Revista Inst. Adolfo Lutz. 71(1): 1-10. http://periodicos.ses.sp.bvs.br/scielo.php?script=sci_arttexta ndpid=S0073-98552012000100001 andlng=ptandtlng=pt.

Soto VZ, Pérez LL, Estrada AD. 2016. Bacteria causing of foodborne diseases: an overview at Colombia. Revista Salud Uninorte, 32(1): 105-122. http://www.scielo.org.co /pdf/sun/v32n1/v32n1a10.pdf

Tafur G. 2009. La inocuidad de alimentos y el comercio internacional. Rev Colomb Cienc Pec. 22(3): 330-338. http://www.redalyc.org/articulo.oa?id=295023525009

Tafur JD, Torres JA, Villegas MV. 2011. Mechanisms of antibiotic resistance in Gram negative bacteria. Infectio, 12(3):217-226.

Torres K, Sierra S, Poutou R, Carrascal A, Mercado M. 2005. Pathogenesis of Listeria monocytogenes, microorganism zoonotic emergent. Rev. MVZ Cordoba, 10(1): 511-543.

USDA. 2019. Method 8.11. Isolation and Identification of Listeria monocytogenes from Red Meat, Poultry, Ready-ToEat Siluriformes (Fish) and Egg Products, and Environmental Samples. Microbiology Laboratory Guidebook (MLG). United States Department of Agriculture (USDA). Food Safety and Inspection Service (FSIS). https://www.fsis.usda.gov/wps/portal/fsis/topics/science/lab oratories-and-procedures/guidebooks-and-

methods/microbiology-laboratory-guidebook

Vera A, González G, Domínguez M, Bello H. 2013. Main virulence factors of Listeria monocytogenes and its regulation. Rev Chilena Infectol. 30(4): 407-416. https://dx.doi.org/10.4067/S0716-10182013000400010

Verraes C, Van Boxstael S, Van Meervenne E, Van Coillie E, Butaye P, Catry B, Daube G. 2013. Antimicrobial resistance in the food chain: a review. Int. J. Environ. Res. Public Health, 10(7): 2643-2669. DOI:10.3390/ijerph10072643

WHO. 2017. Food safety. Wolrd Health Organization. United Nations Organization. https://www.who.int/news-room/factsheets/detail/food-safety

WHO. 2019. Health topics. Antimicrobial resistance. World Health Organization. United Nations Organization. https://www.who.int/topics/antimicrobial_resistance/en/

WHO. 2019. Health topics. Foodborne diseases. World Health Organization. United Nations Organization. https://www.who.int/topics/foodborne_diseases/en/

WHO. 2018. Listeriosis. World Health Organization. United Nations Organization. https://www.who.int/ith/diseases/listeriosis/en/

Wieczorek K, Osek J. 2017. Prevalence, genetic diversity and antimicrobial resistance of Listeria monocytogenes isolated from fresh and smoked fish in Poland. Food Microbiol. 64: 164-171. https://doi.org/10.1016/j.fm.2016.12.022

Zorn BG, Suárez R. 2009. Listeria y Listeriosis. Profesión veterinaria, 71: 58-67. http://www.colvema.org/PDF/5667Listeria.pdf 